\section{Paweł Podeszwa}

Uniwersytet im. Adama Mickiewicza w Poznaniu

e-mail: podpaw@amu.edu.pl

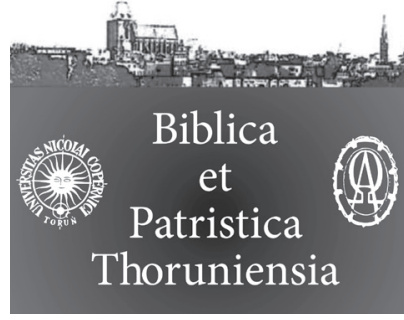

8 (2015) 2 ISSN 1689-5150

\title{
„Obroń mnie przed moim przeciwnikiem" (Łk 18,3). Status wdowy w Opus Lucanum
}

\section{"Grant me justice against my adversary" (Luke 18:3). The status of a widow in Opus Lucanum}

Streszczenie. W niniejszym artykule proponuję refleksję nad statusem (sytuacją) wdów wymienionych w Dziele Łukaszowym, aby odpowiedzieć na pytanie: czy w powyższych tekstach nowotestamentowych możemy odnaleźć jakąkolwiek sugestię teoretycznej czy praktycznej przemocy wobec tej szczególnej grupy kobiet? Niniejsza prezentacja składa się z czterech części: pierwsza dotyczy samego terminu greckiego „wdowa” i jego użycia w pismach Łukaszowych; drugi punkt zawiera omówienie tekstów z Trzeciej Ewangelii, gdzie wymienione są wdowy: prorokini Anna (2,36-37); fragment mowy inauguracyjnej Jezusa w synagodze w Nazarecie, kiedy wspomina, że „wiele wdów było w Izraelu w czasach Eliasza $(4,25)$, ale prorok został posłany do „wdowy w Sarepcie Sydońskiej” $(4,26)$; wdowa $z$ Nain $(7,12)$; przypowieść o sędzi i wdowie $(18,3.5)$; wypowiedź Jezusa o nauczycielach Pisma, którzy „objadają domy wdów” $(20,47)$ oraz opowiadanie o wdowim groszu $(21,2.3)$. W trzeciej części poddane zostają analizie dwa teksty z Dziejów Apostolskich: opowiadania o wyborze Dwunastu, kiedy Łukasz pisze, że Helleniści zaczęli narzekać na Hebrajczyków, twierdząc, że „ich wdowy są niesprawiedliwie traktowane podczas codziennej posługi" $(6,1)$ oraz opowiadanie o wskrzeszeniu Tabity, kiedy autor wspomina o obecności wdów, którym pomagała Gazela (9,39.41). Końcowa część artykułu stanowi podsumowanie i ukazuje wdowę jako adresata miłosierdzia Jezusa i wspólnoty chrześcijańskiej. Według Łukasza wdowa jest także symbolem gościnności, ufności Bogu, zawierzenia, poświęcenia, całkowitego oddania Bogu.

Analizowane fragmenty pozwalają stwierdzić jednoznacznie, że w Opus Lucanum nie znajdujemy jakiejkolwiek sugestii przemocy wobec wdów. Co więcej, prezentowane teksty zobowiązują wyznawców Jezusa do swoistego rodzaju miłosiernej łagodności wobec potrzebujących kobiet, jakimi są niewątpliwie wdowy. Jednoznacznie przestrzegają przed jakąkolwiek formą ucisku i wykorzystywania ich słabej społecznie pozycji. Piętnują wszelkie tego typu zachowania, jak objadanie domów wdów przez faryzeuszy $(20,47)$ oraz brak zainteresowania ich trudnym losem i odmowa pomocy, jak w przypadku niesprawiedliwego sędziego $(18,4)$, czy jakąkolwiek formę zaniedbywania posługi charytatywnej (Dz 6,1). Zwłaszcza Dzieje Apostolskie, które ukazują pierwsze 
lata życia wspólnoty uczniów Jezusa, zalecają jednoznacznie nawet swoistego rodzaju „strukturalną” opieką nad wdowami, co zostanie jeszcze bardziej wyakcentowane przez tradycję Pawłową, zwłaszcza w listach pasterskich.

Abstract. In the present article I propose a reflection on the status (situation) of widows named in Luke's Work in order to answer the question: can we find in the above New Testaments texts any suggestion of theoretical or practical violence towards this specific group of women? The article is composed of four parts: the first one pertains to the Greek term of "widow" and its use in Luke's writings; the second point contains the treatment of texts from the Third Gospel where widows are mentioned: Anna the Prophetess (2:36-37); a fragment of Jesus' inaugural address in the Nazareth synagogue where Jesus says that "there were many widows in Israel in Elijah's time (4:25) but the prophet was sent to "a widow in Zarephath in the region of Sidon" (4:26); a widow of Nain (7:12); the parable of the unjust judge and the persistent widow (18:3-5); Jesus' statement about the teachers of the law who "devour widows' houses" (20:47) and the story of the widow's mite (21:2-3). The third part contains the analysis of two texts from the Acts of the Apostles: the story of the choosing of the Twelve where Luke writes that the Hellenistic Jews complained against the Hebraic Jews claiming that "their widows were being overlooked in the daily distribution of food" (6:1) and the story of Tabitha being raised from the dead where the author mentions the presence of widows who were helped by the Gazelle (9:39-41). The final part of the article is a summary and reveals a widow as the recipient of Jesus' and Christian community's mercy. According to Luke, a widow is a symbol of hospitality, trust in God, faith, sacrifice and unconditional commitment to God.

The analyzed fragments allow to state unequivocally that in Opus Lucanum we do not find any suggestion whatsoever of violence against women. What is more, the presented texts oblige Jesus' followers to a specific kind of merciful gentleness towards distressed women, with widows being undoubtedly thought as such. The texts warn explicitly against any form of oppression and unfair use of widows' weak social position. They stigmatize all instances of this type of behaviour, such as devouring widows' houses by the Pharisees (20:47), lack of interest in widows' plight and refusal to help them, as in the case of the unjust judge (18:4), or any form of neglect in charitable acts (Acts 6:1). The Acts of the Apostles, which show the first years of the existence of the community of Jesus' disciples, recommend in particular a specific kind of "structural" care of widows, which was even more markedly stressed by St Paul's tradition, especially in pastoral epistles.

Słowa kluczowe: kobieta; wdowa; Opus Lucanum; przemoc; miłosierdzie; prorokini Anna; wdowa z Nain; wdowa z Sarepty Sydońskiej; natrętna wdowa; wdowi grosz; Tabita.

Keywords: woman; widow; Opus Lucanum; violence; mercy; Anna the Prophetess; widow of Nain; widow of Zarephath; persistent widow; widow's mite; Tabitha. 


\section{Ł}

ukasz, autor trzeciej ewangelii kanonicznej oraz Dziejów Apostolskich, określany jest niekiedy mianem „ewangelisty kobiet”, gdyż w swoim podwójnym dziele ${ }^{1}$ szczególne miejsce przypisuje niewiastom i podkreśla ich rolę w misji Jezusa i pierwotnego Kościoła ${ }^{2}$. Jedynie Łukasz wspomina, że poza Dwunastoma towarzyszyło Jezusowi również kilka kobiet (Łk 8,2-3), które należały do grona Jego uczniów, choć wprost nie zostały nazwane uczennicami Jezusa ${ }^{3}$. Wśród wymienianych kobiet ważną grupę zajmują wdowy, którym Łukasz poświęca sporo uwagi w swoich pismach. Była to szczególna kategoria kobiet. Wdowy wzmiankowane prawie 100 razy w Biblii często są „archetypem smutku i opuszczenia" ${ }^{4}$, symbolem samotności, słabości i niejednokrotnie bezradności. Często są wymieniane wraz z sierotami i obcymi, a zatem ludźmi najbardziej doświadczonymi i nieszczęśliwymi (Wj 22,21.24; Pwt 10,18; $24,17.19-21 ; 26,12-13 ; 27,19 ;$ Jr 22,3)5. Można zatem powiedzieć, że znajdują się w tak trudnej sytuacji życiowej, że mogą stać się ofiarami łatwych nadużyć, wykorzystywania oraz rozmaitych form ucisku, czy nawet przemocy.

W niniejszym artykule proponuję refleksję nad statusem (sytuacją) wdów wymienionych $\mathrm{w}$ Dziele Łukaszowym, aby odpowiedzieć na pytanie: czy w powyższych tekstach nowotestamentowych możemy odnaleźć jakąkolwiek sugestię teoretycznej czy praktycznej przemocy wobec tej szczególnej grupy kobiet? ${ }^{6}$ Niniejsza prezentacja składa się z czterech części: pierwsza dotyczy samego terminu greckiego „wdowa” i jego użycia w pismach Łukaszowych; drugi punkt zawiera omówienie tekstów z Trzeciej Ewangelii, gdzie wspomniane są wdowy; w trzeciej części poddane zostaną analizie dwa teksty z Dziejów Apostolskich; natomiast czwarty punkt jest podsumowaniem i próbą odpowiedzi na postawione wcześniej pytanie o przemoc wobec wdów.

1 Na temat jedności literackiej i teologicznej Ewangelii według św. Łukasza i Dziejów Apostolskich, zob. W. Rakocy, „Będziecie moimi świadkami...” (Dz 1,8), s. 14-16; D. Kotecki, „Droga” jako element jedności, s. 55-76.

2 Na temat specyfiki Łukaszowego zainteresowania kobietami, zob. P. Mourlon Beernaert, Maria, Marta i inne, s. 246-256. Według wielu autorów to zainteresowanie Łukasza kobietami jest motywowane przede wszystkim chęcią wyakcentowania równości obu płci wobec Boga, a zatem również równości w zakresie pozycji społecznej i przyczynianiu się do wzrostu Królestwa Bożego, zob. R. Rubinkiewicz, Pozycja społeczna kobiety, s. 61-62.

3 Zob. Fr. Mickiewicz, Ewangelia, cz. 1, s. 413.

4 Wdowa, s. 1074.

5 Zob. P. Ostański, Skądże nadejdzie mi pomoc?, s. 64.

6 Takie ukierunkowanie tematu zostało podyktowane faktem, że niniejszy artykuł był wygłoszony jako referat podczas sympozjum naukowego zorganizowanego przez Katedrę Biblijną WT UMK w Toruniu pod tytułem „Przemoc wobec kobiety w Biblii?”, dnia 14 maja $2015 \mathrm{r}$. 


\section{Grecki termin „wdowa” i jego występowanie w Opus Lucanum}

Według językoznawców grecki rzeczownik $\chi \eta ́ p \alpha$ wywodzi się z indoeuropejskiego pnia ghê, który oznacza opuszczony, pozostawiony pusty, opustoszały i jest używany w literaturze greckiej poczynając od Homera ${ }^{7}$. Termin ten jest

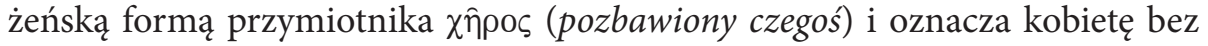
męża ${ }^{8}$, a zatem zarówno wdowę, jak i żyjącą bez męża. W literaturze greckiej termin był stosowany $\mathrm{w}$ obu znaczeniach, czego dowodem jest imię bogini Hery, które otrzymała, kiedy żyła w rozłące z Zeusem ${ }^{9}$. W LXX termin ten jest używany powszechnie na oznaczenie wdowy, tylko w 2 Sm 20,3 odnosi się do kobiety odseparowanej od męża.

W Nowym Testamencie rzeczownik ten występuje 26 razy $^{10}, \mathrm{z}$ czego aż 12 razy w Opus Lucanum (9 razy w Łk 2,37; 4,25.26; 7,12; 18,3.5; 20,47, 21,2.3 oraz 3 razy w Dz 6,1;9,39.41). Aż 6 razy termin ten pojawia się w materiale własnym Trzeciej Ewangelii: po raz pierwszy w odniesieniu do prorokini Anny, która żyła w małżeństwie siedem lat i pozostała wdową (2,36-37); w mowie inauguracyjnej Jezusa w synagodze w Nazarecie, kiedy wspomina, że „wiele wdów było w Izraelu w czasach Eliasza $(4,25)$, ale prorok został posłany do „wdowy w Sarepcie Sydońskiej” (4,26); w opisie wskrzeszenia młodzieńca z Nain, którego matka była wdową $(7,12)$; w przypowieści o sędzi i wdowie $(18,3.5)$. Pozostałe trzy występowania rzeczownika $\chi \eta ́ p \alpha$ odnajdujemy w tekstach pochodzących z tradycji Markowej: w wypowiedzi Jezusa o nauczycielach Pisma, którzy „objadają domy wdów” $(20,47)$ oraz w opowiadaniu o wdowim groszu $(21,2.3)$. W Dziejach Apostolskich, które stanowią drugą Księgę Opus Lucanum, termin pojawia się trzykrotnie: na początku opowiadania o wyborze Dwunastu, kiedy Łukasz pisze, że Helleniści zaczęli narzekać na Hebrajczyków, twierdząc, że „ich wdowy są niesprawiedliwie traktowane podczas codziennej

7 G. Stählin, $\chi \eta^{\prime} \rho \alpha$, k. 704.

8 H. Langkammer, Znaczenie o rola kobiety, s. 50.

9 Zob. P. Ostański, Skądże nadejdzie mi pomoc?, s. 63. Autor pisze także na temat hebrajskiej terminologii wdowieństwa (s. 62-63). Zwraca uwagę, że termin hebrajski 'almânâ przypomina inny termin hebrajski 'âlam (być niemym, zamilknać) i stąd możliwe także znaczenie, według niektórych komentatorów, że wdowa powinna milczeć w swoim bólu i bez słowa przyjmować trudny los (s. 65).

10 Nie uwzględniamy wariantu tekstualnego dla Mt 23,14, gdzie pod wpływem Mk 12,40 oraz Łk 20,47 niektóre rękopisy i Wulgata mają dodatek o objadaniu wdów przez faryzeuszy. Poza tekstami Łukaszowymi termin ten występuję 14 razy w Nowym Testamencie: Mk 12,40.42.43; 1 Kor 7,8; 1 Tm 5,3bis.4.5.9.11.16bis; Jk 1,27; Ap 18,7. 
posługi" $(6,1)$ oraz dwa razy w opowiadaniu o wskrzeszeniu Tabity, kiedy autor wspomina o obecności wdów, którym pomagała Gazela (9,39.41).

\section{Wdowy w Ewangelii według Łukasza}

Rozpoczynamy od lektury Ewangelii, aby prześledzić wszystkie teksty, w których pojawią się rzeczownik $\chi \eta ́ p \alpha$.

\section{Prorokini Anna (2,36-37)}

Jak już zostało powiedziane, pierwsza wzmianka o wdowie pojawia się w Trzeciej Ewangelii w obrębie Łukaszowej Ewangelii Dzieciństwa w perykopie o ofiarowaniu Jezusa w świątyni (2,22-24), która staje się także miejscem spotkania z Symeonem (2,25-35) oraz Anną (2,36-38). Bezpośrednio po proroctwie Symeona ewangelista wspomina Annę, którą najpierw nazywa "prorokinią"

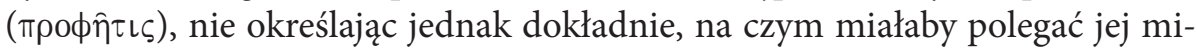
sja $^{11}$. Już w Starym Testamencie spotykamy prorocki charyzmat kobiet, takich jak Miriam (Wj 15,20); Debora (Sdz 4,4-10) oraz Chulda, żyjąca w czasach Jeremiasza $(2 \mathrm{Krl} 22,14)^{12}$. Łukasz dość dokładnie charakteryzuje Annę jako córkę Fanuela, pochodzącą z pokolenia Asera ${ }^{13}$. Kolejna informacja dotyczy jej stanu cywilnego oraz wieku. Łukasz zaznacza, że owdowiała po siedmiu latach małżeństwa i miała już osiemdziesiąt cztery lata, co w rezultacie pozwala Łukaszowi nazwać ją „sędziwą” lub „podeszłą w latach”. Wiek kobiety sprawie pewną trudność interpretacyjną, gdyż tekst można rozumieć także, że jako wdowa przeżyła osiemdziesiąt cztery lata ${ }^{14}$, co by oznaczało, że w chwili spotkania

11 Zdaniem M. Bednarz, Bierz i czytaj, s. 127 poprzez określenie Anny prorokinią Łukasz chce zaznaczyć, że podobnie jak Symeon, została oświecona i dzięki temu dostrzegła w wydarzeniach zbawczy plan Boga.

12 Zob. Fr. Mickiewicz, Ewangelia, cz. 1, s. 190.

13 Na temat możliwego wpływu tradycji żydowskiej i postaci Serach, córki Asera, zob. M. Remaud, Prophétesse, s. 31-46. Na temat znaczenie symbolicznego użytych imion, zob. S. Fausti, Wspólnota czyta Ewangelię, s. 80: „Anna ('sympatia, łaska u Boga'), córka Fanuela ('oblicze Boga'), z pokolenia Asera ('dobry, los, szczęście’), dzięki Bożej łasce ma szczęście ujrzeć oblicze Boga w obliczu Jezusa”.

14 Na temat symbolicznego znaczenie tej liczby, zob. M. Bednarczyk, Perykopa o Annie, s. 78, gdzie czytamy «Liczba 84 to $12 x 7:$ „12” symbolizuje cały „Izrael” a „7” oznacza pełnię i doskonałość. E. Burrows w swym dziele liczbę 84 nazywa „rachunkiem sztucznym”. Jeżeli Łukasz przyjmuje, że okres wdowieństwa Anny trwał aż 84 lata, gdy do tego dodamy 7 lat pożycia małżeńskiego oraz 14 lat życia przed zamążpójściem, (w tym wieku można już było 
z Jezusem miała ponad sto lat ${ }^{15}$. Z kontekstu można także wywnioskować, że była bezdzietna, choć wprost nie zostało to powiedziane. Pewne jest natomiast, że po śmierci męża nie wyszła ponownie za mąż i pozostała wdową. Zdaniem H. Schürmanna Łukasz idealizuje w ten sposób stan wdowieństwa, a „Anna jest przedstawiona jako model dla wdów chrześcijańskich”" ${ }^{16}$. Ponadto ewangelista charakteryzuje Annę jako pobożną wdowę, ponieważ „nie opuszczała świątyni, służąc Bogu w postach i modlitwach, dniem i nocą" (Łk 2,37). Pierwszej informacji nie należy rozumieć, że prorokini na stałe przebywała $\mathrm{w}$ świątyni ${ }^{17}$, mieszkając w swoistego rodzaju „klauzurze"18, ale raczej chodzi o częste, może nawet codzienne, przychodzenie do świątyni, aby służyć Bogu ${ }^{19}$. Łukasz używa czasownika $\lambda \alpha \tau \rho \in \dot{\omega} \omega$, który ma wymiar kultyczny. Z powodu swojej sytuacji ekonomicznej, w której się znajdowała jako bezdzietna wdowa, nie miała możliwości składać Bogu ofiar całopalnych, stąd składała w ofierze „posty i modlitwy". Użycie liczby mnogiej obu rzeczowników podkreśla częstotliwość wspomnianych praktyk religijnych. Postawa Anny jest świadectwem, „że swe-

zawierać małżeństwo), to okaże się, że Anna prorokini w czasie spotkania ze Świętą Rodziną miała co najmniej 105 lat, a więc była kobietą bardzo starą. Wydaje się jednak, że Łukasz, mówiąc o 84 latach jej wdowieństwa, pragnie nawiązać do biblijnej bohaterki Judyty, która po śmierci swego męża Manassesa $(J d t 8,2)$ nie wyszła powtórnie za mąż, ale jako wdowa zmarła mając 105 lat. Niewątpliwie tak bardzo podkreślone przez Łukasza wdowieństwo Anny jest zastanawiające i należy chyba przyjąć za P. Sondevoirem, że przy końcu czasów starotestamentalnych daje się zauważyć szczególny szacunek dla stanu wdowieństwa. Przykładem jest tu wspomniana już Judyta, która po śmierci męża prowadziła życie samotnie, umartwiała się $(J d t 8,6)$ i oddawała modlitwie dniem i nocą (Jdt 11, 17). Łukasz w Annie prorokini widzi nową Judytę, która - jako wdowa - służyła Bogu trwając w postach i modlitwach dniem i nocą ( $£ k 2,37)$ ».

15 Taki przekład proponuje Biblia Poznańska: „Po wyjściu za mąż żyła siedem lat z mężem, a we wdowieństwie osiemdziesiąt cztery lata". W przypisie czytamy natomiast, że przy takim rozumieniu tekstu Anna miałaby około 105 lat, zob. Pismo Święte, s. 158, przypis do wersetów 36-38, zob. także H. Schürmann, Il vangelo, s. 257.

16 Ibidem. Zdaniem M. Bednarczyk, Perykopa o Annie, s. 79 [64-83] „autor biblijny przedstawił Annę jako świetlany przykład wdowy. Wzmiankowane zalety tej kobiety predysponowałyby ją zapewne do rangi wdowy godnej wpisania nawet do specjalnego katalogu w związku z istniejącą instytucją wdów w Kościele Apostolskim, o której wspomina

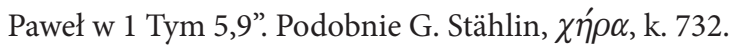

17 Zdaniem M. Mikołajczaka, Proklamacja tożsamości Jezusa, s. 191 mamy tutaj wy-

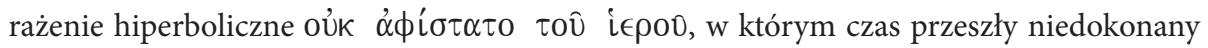
Łukaszowego czasownika nieprzechodniego sugeruje w wyraźny sposób długotrwałość

18 Zob. H. Schürmann, Il vangelo, s. 257

19 Zdaniem G. Stählina, $\chi \eta ́ \rho \alpha, k .733$ Anna poprzez fakt wytrwałej obecności w świątyni jest także symbolem pierwotnej wspólnoty chrześcijańskiej (Łk 24,53; Dz 2,46). 
go ubóstwa po śmierci męża nie potraktowała jako przekleństwa, ale ujrzała w nim okoliczność sprzyjającą oddaniu się na wyłączną służbę Bogu"20. Warto jeszcze zwrócić uwagę na występujące określenie „dniem i nocą”, które wyraża przede wszystkim ideę trwania, ale być może poprzez to odwołanie Anna staje się także symbolem dwunastu pokoleń Izraela, które oczekują spełnienia się obietnicy, „gorliwie służąc Bogu dniem i nocą" (Dz 26,7)21. Prorokini Anna jest również jednym z pierwszych świadków spełnienie się owej obietnicy, gdyż rozpoznaje w Jezusie oczekiwanego Mesjasza, stąd „wielbiła Boga i opowiadała o Nim wszystkim, którzy oczekiwali wyzwolenia Jeruzalem” (Łk 2,38). W ten sposób Łukasz podkreśla wagę świadectwa kobiet we wspólnocie pierwotnego Kościoła ${ }^{22}$.

\section{Wdowa z Sarepty Sydońskiej $(4,26)$}

Kolejne dwie wzmianki o wdowach znajdujemy na samym początku Jezusowego nauczania w synagodze w Nazarecie $(4,16-30)$, kiedy po odczytaniu fragmentu z proroka Izajasza $(4,17-19)$ Jezus rozpoczyna mowę (4,21-27) wyjaśniając cel swego posłannictwa oraz Boży plan zbawienia, który obejmuje także pogan. Jezus odwołuje się do dwóch przykładów ze Starego Testamentu: suszy i klęski głodu za czasów proroka Eliasza, kiedy to został posłany przez Boga do wdowy z Sarepty (1 Krl 17,1-24) oraz uzdrowienie trędowatego wodza syryjskiego Naamana przez Elizeusza ( $2 \mathrm{Krl}$ 5,1-27). Pierwsza wzmianka o wdowach znajduje się w stwierdzeniu Jezusa, że „wiele wdów było w Izraelu w czasach Eliasza, kiedy niebo zostało zamknięte na trzy lata i sześć miesięcy, tak iż w całym kraju nastał wielki głód” (Łk 4,25) ${ }^{23}$. Można z łatwością wyobrazić sobie położenie zwłaszcza wdów i sierot podczas klęski suszy i nieurodzaju. Jednak prorok Eliasz został posłany przez Boga poza granice Izraela (passivum divinum) do

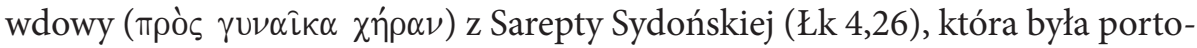
wym miastem fenickim, położonym $12 \mathrm{~km}$ na południe od Sydonu i $22 \mathrm{~km}$ na północ od Tyru24. Jak czytamy w Pierwszej Księdze Królewskiej, mieszkająca

20 Fr. Mickiewicz, Ewangelia, cz. 1, s. 191.

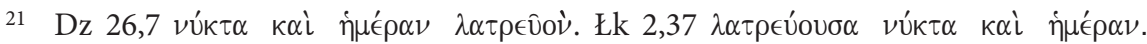
Zob. M. Mikołajczaka, Proklamacja tożsamości Jezusa, s. 192.

22 G. Stählin, $\chi \eta \dot{\rho} \alpha$, k. 732.

23 Susza i głód była karą dla Izraela za bałwochwalstwo i kult Baala, boga deszczu i urodzaju.

24 Mimo iż miasto leżało poza Izraelem i znajdowało się na terytoriach, gdzie czczono Baala, jednak także zostało objęte karą suszy, co miało na celu podważenie wiarygodności bóstwa uznawanego za boga deszczu. 
tam wdowa okazała prorokowi gościnę i miłosierdzie, a w zamian otrzymała pożywienie, dzięki cudowi nie kończącej się mąki i oliwy podczas suszy (1 Krl 17,8-16). Kiedy natomiast zachorował i umarł jej syn prorok Eliasz wskrzesił go i oddał zdrowego matce (1 Krl 17,17-23). W ten sposób wdowa z Sarepty jest symbolem dobroci, otwartości, ufności, która zostaje wynagrodzona przez samego Boga Izraela, który posyła proroka Eliasza (1 Krl 17,8; Łk 4,26). Jahwe jest przecież „ojcem dla sierot i dla wdów opiekunem” (Ps 68,6), wysłuchuje ich płaczu (Wj 22,21-23), dostarcza im pożywienia i odzienia (Pwt 10,18) oraz ochrania ich dziedzictwo $(\operatorname{Prz} 15,25)^{25}$.

Wdowa z Sarepty została także ukazana jako poganka, która rozpoznała w proroku męża Bożego i słowo Pana, które rzeczywiście spełniło się przez niego $(1 \mathrm{Krl} 17,24)$. W takim też znaczeniu jest przywołana przez Jezusa w Trzeciej Ewangelii dla ilustracji Jego misji o Bożego zbawienia, który wykracza poza granice Izraela, gdyż wszystkie narody, zatem także poganie, mają poznać i wyznać jedynego Boga Izraela jako swego Pana i Zbawiciela.

\section{Wdowa z Nain $(7,12)$}

Trzeci fragment, w którym wzmiankowana jest wdowa, podobnie jak dwa poprzednie, należy do materiału własnego Łukasza. Jest to opowiadanie o wskrzeszeniu młodzieńca z Nain (7,11-17). Po uzdrowieniu sługi setnika w Kafarnaum $(7,1-10)$, Jezus udał się do małego miasteczka w Galilei, położonego na południowy wschód od Nazaretu, którego ewangeliczna nazwa brzmi Nain i pojawia się tylko w tym miejsce w całej Biblii. Kiedy zbliżał się do bramy miasta napotkał kondukt pogrzebowy. Wynoszono właśnie poza miasto zmarłego jedynego syna pewnej wdowy, która mieszkała w Nain. Ta wzmianka o jedynym synu ma swoją wagę, gdyż według obowiązującego wówczas zwyczaju wdowa nie miała prawa dziedziczenia po mężu ${ }^{26}$. Przysługiwało ono wyłącznie synowi lub krewnym ze strony męża ${ }^{27}$. Wdowa była zatem całkowicie zdana na ich opiekę i wsparcie ${ }^{28}$. Śmierć jedynego syna „oznaczała zatem dla wdowy popadniecie w sytuację skrajnego ubóstwa, bez żadnej opieki i wsparcia finanso-

25 Zob. P. Ostański, Skądże nadejdzie mi pomoc?, s. 65-66.

26 Zob. S. Szymik, Małżeństwo, s. 222-223.

27 Zob. P. Ostański, Skądże nadejdzie mi pomoc?, s. 64.

28 Prawo lewiratu, o którym czytamy w Pwt 25,5 miało za zadanie regulować kwestie związane z dziedziczeniem, aby dać wdowie, poprzez syna po zmarłym mężu, dostęp do jego majątku, a tym samym utrzymanie. Na temat innych przepisów, które miały bronić pozycji wdowy, zob. A. Banaszek, Prawdziwa pobożność, s. 68. 
wego"29. Jak słusznie zauważa S. Fausti: «Jest to matka „wdowa” - bez małżonka, bez miłości i bez obrony, uboga i opuszczona. Pozbawiona praw i tożsamości nie może nabyć ich nawet w synu, bo jest martwy!"30. Zauważenie i świadomość tej beznadziejnej sytuacji wdowy (ona nie prosi Jezusa o pomoc) spowodował głębokie wzruszenie Jezusa, które ewangelista wyraża przy pomocy czasownika

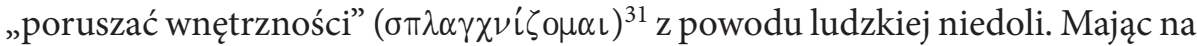
uwadze znaczenie tego czasownika greckiego oraz jego odpowiedników hebrajskich, którymi są rzeczowniki: łono (rehem) i litość, miłosierdzie (rahamim $)^{32}$ nie chodzi tutaj tylko i wyłącznie o ludzkie współczucie czy solidarność z potrzebującym, ale uczucie Jezusa jest wyrazem przede wszystkim Bożego miłosierdzia, które oznacza gotowość Boga do ratowania człowieka z każdej sytuacji materialnej czy duchowej zagrażającej jego egzystencji. Co więcej, „Bóg uprzedza i nawiedza bez prośby, modlitwy czy wiary tego, kto jest całkowicie zagubiony i już nie może prosić, modlić się ani wierzyć" ${ }^{33}$. To miłosierdzie Boże objawia się w słowie i geście Jezusa, który wskrzesza młodzieńca i oddaje go matce. Wdowa staje się zatem adresatem Bożego miłosierdzia, bo Bóg lituje się nad niedolą człowieka. Jak zauważa słusznie M. Bednarz, „opis tego wy-

29 Fr. Mickiewicz, Ewangelia, cz. 1, s. 380.

30 S. Fausti, Wspólnota czyta Ewangelię, s. 230.

31 U Łk termin ten występuje jeszcze tylko dwa razy w 10,33 w przypowieści o miłosiernym Samarytaninie oraz w 15,20 w przypowieści o miłosiernym Ojcu.

32 «Drugie z wyrażeń, które w słownictwie Starego Testamentu służy dla określenia miłosierdzia to rahamim. Posiada ono inne niż hesed zabarwienie. O ile bowiem to poprzednie uwydatnia cechy wierności samemu sobie i „odpowiedzialności za własna miłość” (a więc cechy jak gdyby męskie), o tyle rahamim już w swym źródłosłowie wskazuje na miłość matczyna (rehem = łono matczyne). Z tej najgłębszej, pierwotnej bliskości, łączności i więzi, jaka łączy matkę z dzieckiem, wynika szczególny do tegoż dziecka stosunek, szczególna miłość. Można o niej powiedzieć, że jest całkowicie darmo dana, nie zasłużona, że w tej postaci stanowi ona jakąś wewnętrzną konieczność: przymus serca. Jest to jakby „kobieca” odmiana owej męskiej wierności sobie samemu, o jakiej mówi hesed. Na tym podłożu psychologicznym rahamim rodzi całą skalę uczuć, a wśród nich dobroć i tkliwość, cierpliwość i wyrozumiałość, czyli gotowość przebaczania. Takie też cechy Stary Testament przypisuje Bogu, ilekroć, mówiąc o Nim, posługuje się tym wyrażeniem rahamim. Czytamy u Izajasza: „Czyż może niewiasta zapomnieć o swym niemowlęciu, ta, która kocha syna swego łona? A nawet gdyby ona zapomniała, Ja nie zapomnę o tobie!" (Iz 49, 15). Ta miłość, wierna i niepokonalna dzięki tajemniczej mocy macierzyństwa, wyraża się w pismach starotestamentalnych na różne sposoby, zarówno w ratowaniu od niebezpieczeństw zwłaszcza od wrogów, jak też w przebaczaniu grzechów - i to zarówno poszczególnych jednostek, jak całego Izraela - a wreszcie w gotowości spełniania obietnicy i nadziei (eschatologicznych), i to pomimo ludzkiej niewierności. Jak czytamy u Ozeasza: „uleczę ich niewierność i umiłuję z serca" (Oz 14, 5)», Jan Paweł II, Dives in misericordia.

33 S. Fausti, Wspólnota czyta Ewangelię, s. 229. 
darzenia zmierza do jednego jeszcze celu. Św. Łukaszowi zależało na dowartościowaniu roli kobiety. Niewiasta, która jest również stworzeniem Bożym, była spychana przez judaizm ma margines życia. Ewangelista chce podkreślić to, co było ustawiczną troską Jezusa: zjednoczyć całą ludzkość, czyli mężczyzn i kobiety, bogatych i biednych, Żydów i pogan"34. Być może w ten sposób także ewangelista przypomina wspólnocie Kościoła o konieczności naśladowania Chrystusa w jego postawie miłosierdzia względem potrzebujących, zwłaszcza najsłabszych, do grona których należą niewątpliwie wdowy.

\section{Nieustępliwa wdowa $(\mathbf{1 8 , 1 - 8 )}$}

Kolejna wdowa, którą spotykamy w Trzeciej Ewangelii, pojawia się w przypowieści Jezusa o niesprawiedliwym sędzi i wdowie $(18,1-8)$. Jak informuje nas werset wprowadzający, Jezus opowiedział tę przypowieść uczniom „o tym, że zawsze powinni się modlić i nie zniechęcać się”, stąd można by ja nazwać „przypowieścią o konieczności ciągłej modlitwy"35.

W gronie bohaterów przypowieści pojawią się najpierw sędzia. Był on wykształconym urzędnikiem, który miał bezstronnie i sprawiedliwie rozstrzygać spory i w ten sposób dbać o utrzymanie sprawiedliwości w narodzie. W praktyce często jednak strona silniejsza sporu próbowała wywierać nacisk na sędziego, próbując go przekupić i łapówkami zdobyć jego przychylność oraz korzystne dla siebie rozstrzygnięcie sporu ${ }^{36}$. W przypowieści sędzia przedstawiony jest jako ten, który nie boi się Boga i nie liczy się z ludźmi (18,2), to znaczy „jest «praktycznym ateistą», którego nie obchodzi ani Bóg, ani Jego prawo, a zarazem jest na tyle pewnym swej pozycji, że nie musi się liczyć z innymi ludźmi" ${ }^{37}$. Stąd nazwany jest „niesprawiedliwym” (Łk 18,6), a jego postawa zaprzecza istocie misji sędziego, któremu powierzył troskę o stanie na straży sprawiedliwości (Pwt 1,16-18) oraz sprawiedliwego, niestronniczego i nieprzekupnego sądzenia (2 Krn 19,5-7).

Drugim bohaterem przypowieści Jezusa jest właśnie wdowa, która także mieszkała w mieście i przyszła do sędziego z prośbą, aby ten obronił ją przed jej przeciwnikiem (Łk 18,3). Wdowa po śmierci męża jest pozbawiona prawnej obrony z jego strony, zatem pozostając sama, musi prosić o pomoc sędziego. Przypowieść nie precyzuje o jaką krzywdę chodzi, ale fakt, że jest zmuszona

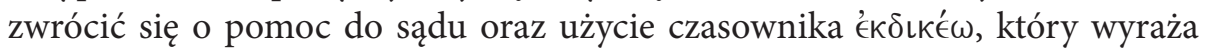

\footnotetext{
M. Bednarz, Bierz i czytaj, s. 246.

35 Fr. Mickiewicz, Ewangelia, cz. 2, s. 252.

36 Zob. A. Paciorek, Przypowieści Jezusa, s. 372.

37 Fr. Mickiewicz, Ewangelia, cz. 2, s. 252.
} 
ideę pomszczenia lub ukarania sugeruje, że chodzi o „wymierzenie sprawiedliwości, a więc także o obronę przed przeciwnikiem i nałożenie mu stosownej kary za wyrządzenie krzywdy bezbronnej osobie”38. Według Fr. Mickiewicza to, że szuka pomocy u sędziego może wskazywać, że „chodzi o jakąś należność pieniężną, zwlekanie z wypłatą jakiejś sumy za wykonaną pracę lub może nawet i próbę odebrania jej jakiejś własności" ${ }^{39}$.

Jak czytamy dalej w przypowieści, sędzia początkowo nie chciał wziąć w obronę pokrzywdzonej wdowy i odraczał jej sprawę, może także dlatego, że nie mógł liczyć z jej strony na odpowiednie wynagrodzenie. Jednak usilna i wytrwała prośba ze strony wdowy skłoniły go w końcu do zajęcia się jej prośbą, choć motywem nie jest chęć zadbania o sprawiedliwość, ale raczej fakt, że ma dosyć naprzykrzania się ze strony kobiety $(18,5)$. Najpierw jej prośba określona jest jako częste przychodzenie, gdyż użycie czasu imperfectum ("’ $\chi \in \tau o$ ) w 18,3 wskazuje na wielokrotne powtarzanie tej czynności. Jeszcze ciekawszy

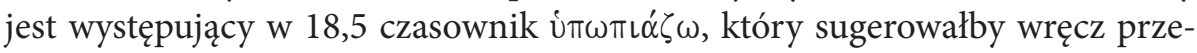
moc fizyczną ze strony naprzykrzającej się wdowy. W świetle etymologii może bowiem oznaczać „podbić komuś oko” i kojarzy się z walką na pięści ${ }^{40}$. Raczej jednak nie należy tego czasownika rozumieć w sensie dosłownym, ale „raczej metaforycznie lub sarkastycznie [...]. Sędzia nie obawia się, że wdowa wywrze na nim fizyczną przemoc (że go pobije), ale że zadręczy go na śmierć swoją natarczywością"41. W ten sposób jej nieugięta i postawa staje się ona symbolem wytrwałej i ufnej prośby, która ostatecznie została wysłuchana i spełniona.

\section{Wdowy objadane przez nauczycieli Pisma $(20,47)$}

W części poświęconej działalności i nauczaniu Jezusa w świątyni jerozolimskiej (Łk 19,28-21,38) odnajdujemy kilka słów, które są adresowane bezpośrednio do uczniów (20,45-47). Są one skoncentrowane na przekonaniu uczniów, aby wystrzegali się nauczycieli w Piśmie, to znaczy, aby nie naśladowali ich nagannego zachowania i uczynków. Jezus ostrzega swoich uczniów $(20,46)$ przed zbytnim przywiązywaniem wagi do bogatego stroju, który miał zaznaczać ich lepszą pozycję społeczną („wytworne szaty”) oraz przed pragnieniem bycia zauważonym i docenionym przez oczekiwanie czy wręcz domaganie się pozdrowień w miejscach publicznych („pozdrowienia na placach”) i zajmowanie zawsze pierwszych miejsc podczas zebrań liturgicznych i przy stole („pierw-

Ibidem, s. 254.

Ibidem, zob. także M. Wojciechowski, Wady jako zalety, s. 115.

Fr. Mickiewicz, Ewangelia, cz. 2, s. 254.

A. Paciorek, Przypowieści Jezusa, s. 375. 
sze krzesła w synagogach i honorowe miejsca na ucztach"). Kolejna przestroga

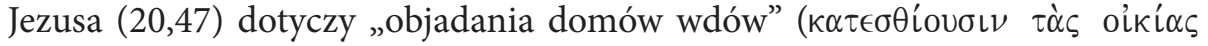
$\tau \hat{\omega} \nu \chi \eta \rho \hat{\nu})$ oraz pozornych długich modlitw. Dosłownie tekst grecki można przełożyć: „pożerają domy wdów”. Wydaje się, że to wyrażenie nie oznacza wyłącznie dosłownego objadania wdów w sensie nadmiernego korzystania z ich gościny przy stole i spożywania posiłków, ale ma znaczenie hiperboliczne i odnosi się do każdej postawy uczonych w Piśmie, która miała na celu wykorzystać trudną sytuację owdowiałych kobiet. Być może chodziło o pobieranie wysokich honorariów za pomoc w obronie ich praw, także w sądzie ${ }^{42}$. Zamiast pomagać tym, którzy są bezbronni, biedni i narażeni na wykorzystanie, sami przyczyniają się jeszcze do pogorszenia ich sytuacji. Już w Starym Testamencie taka postawa była napiętnowana i obwarowana wielką karą dla tych, którzy wykorzystując swoją pozycję społeczną łamali sprawiedliwości i uciskali biednych (Wj 22,21-23; Pwt 10,18; 24,17-22; Iz 1,17.33; 10,2; Jr 7,6; 22,3). Człowiek, który łamał prawa cudzoziemca, sieroty i wdowy został wręcz nazwany przeklętym (Pwt 27,19). Także Jezus stwierdza, że „spotka ich bardzo surowy wyrok” (Łk 20,47).

\section{Ofiarna wdowa $(21,1-4)$}

Bezpośrednio po ostrzeżeniach przed nauczycielami Pisma, które Jezus adresuje do swoich uczniów (Łk 20,45-47), czytamy opowiadanie o wdowim groszu (Łk 21,1-4). Jezus nauczając w świątyni zauważył pewną wdowę, która do skarbonek, znajdujących się na Dziedzińcu Kobiet, wrzuciła ofiarę w postaci „dwóch leptonów” ( $\lambda \in \pi \tau \dot{\alpha} \delta$ b́o). Datki zbierane do 13 skarbonek świątynnych były zasadniczo przeznaczane na potrzeby kultu Bożego. Ofiarowana suma

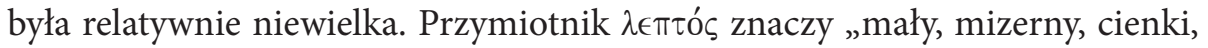
słaby" i słowo to było stosowane na określenie najmniejszej monety z brązu, będącej w obiegu w żydowskim systemie monetarnym. Według Marka $(12,42)$ „dwa leptony” stanowiły wartość jednego rzymskiego kwadransa, to znaczy 1/64 denara, który z kolei według Mateusza był zapłatą za dzień pracy w winnicy (Mt 20,2). Według niektórych komentatorów za dwa leptony było można w czasach Jezus nabyć 100 gramów chleba ${ }^{43}$. To najlepiej ilustruje, że złożona przez wdowę ofiara obiektywnie nie miała wartości materialnej, ale subiektywne znaczyła bardzo wiele, a nawet wszystko, gdyż „ona ze swego ubóstwa wrzuciła wszystko, co miała na swoje utrzymanie" $(21,4)$. To stwierdzenie Jezusa potwierdza jej trudną sytuację materialną. Wdowa była kobietą bardzo ubogą,

\footnotetext{
42 Zob. A. Banaszek, Prawdziwa pobożność, s. 67.

43 Fr. Mickiewicz, Ewangelia, cz. 2, s. 383.
} 
zresztą została określona przez ewangelistę przymiotnikiem $\pi \in \nu\llcorner\chi \rho o ́ \varsigma$, który wyraża skrajne ubóstwo, nawet konieczność żebrania. Sama niewiele posiadała, jednak postanowiła oddać do skarbony świątynnej wszystko. Jej gest był wyrazem i symbolem całkowitego oddania i powierzenia się wyłącznie Bogu. Jak zauważa A. Banaszek, „Oddając swój ostatni grosz, oddała więc Bogu swoją jałmużnę, wszystko, co umożliwiało jej zdobycie pożywienia na następny dzień. Chrystus, który usiadł wtedy naprzeciw skarbony i przypatrywał się składającym ofiarę, tak jakby na nią czekał, aby móc wskazać apostołom człowieka prawdziwie ubogiego, kogoś kto potrafi całkowicie zawierzyć swoje życie Bogu. Uboga wdowa, wyzbywając się swojego jedynego zabezpieczenia na następny dzień, zachwyciła Jezusa, wpisując się na stałe w panoramę ubogich w duchu (anawim), których pochwałę głosi Biblia" ${ }^{44}$.

\section{Wdowy w Dziejach Apostolskich}

Księga Dziejów Apostolskich jest drugim tomem Dzieła Łukaszowego. Pośrednio definiuje się w ten sposób w Prologu, kiedy przywołuje Ewangelię, nazywając ją „Pierwszą Księgą” (Dz 1,1). Dzieje Apostolskie są nazywane często „monografią historyczną" pierwotnego Kościoła, która obejmuje około trzydziestu lat życia i działalności pierwszych wspólnot uczniów Chrystusa. Jak stwierdza jeden ze współczesnych autorów żydowskich Dzieje „oferują prawdziwy wgląd w życie, sposób myślenia i aspiracje pierwszego pokolenia chrześcijan”45. Zgodnie z programem, zarówno literackim, jak i teologicznym, wyrażonym na samym początku, Księga mówi o rozszerzaniu się wiary w Jezusa, Mesjasza i Syna Bożego „W Jerozolimie, Judei, Samarii i aż po krańce ziemi” (Dz 1,8). Apostołowie posłuszni nakazowi Pana - „będziecie moim świadkami” $(1,8)$ - nie tylko wiernie opowiadali o Jezusie i głosili Jego naukę, ale naśladowali Jezusa, przyjmując jako własny Jego styl życia i działania. Wśród wielu elementów łączących czas Jezusa (Ewangelia) i czas Kościoła (Dzieje Apostolskie) jest troska o ubogich, zwłaszcza o wdowy.

A. Banaszek, Prawdziwa pobożność, s. 72.

45

G. Vermes, Twarze Jezusa, Kraków 2008, s. 185. 


\section{Troska wspólnoty o wdowy $(6,1)$}

Jedną z charakterystycznych cech opowiadanej przez Łukasza historii wspólnoty chrześcijańskiej jest fakt, że autor nie przemilcza różnego rodzajów problemów, które pojawiały się w życiu pierwszych wyznawców Chrystusa. I nie chodzi tylko o prześladowania zewnętrzne (5,17-42), ale także o problemy czy nawet spory, które pojawiały się wewnątrz Kościoła (np. grzech Ananiasza i Safiry 5,1-11) oraz wobec wzrastającej liczny chrześcijan („uczniów”46) narzekania Hellenistów na Hebrajczyków, którzy „twierdzili, że ich wdowy są niesprawiedliwie traktowane podczas codziennych posługi" $(6,1)$. Tutaj po raz pierwszy w Dziejach pojawia się interesujący nas rzeczownik w liczbie mnogiej. Chodzi o wdowy wywodzące się z Hellenistów, które miały być w ich mniemaniu zaniedbywane przez Hebrajczyków. Kogo ma na myśli Łukasz, kiedy wspomina te dwie grupy w obrębie pierwotnej wspólnoty? Odpowiedź na to pytanie nie jest jednoznaczna. Z pewnością chodzi o chrześcijan. Jednak termin „Helleniści” jest wieloznaczny. Najczęściej rozumie się go jako odnoszący się do judeochrześcijan wywodzących się z diaspory, którzy posługiwali się językiem greckim, także podczas modlitwy w synagodze (sam termin oznacza „mówiący po grecku”) oraz czytali Stary Testament w przekładzie LXX ${ }^{47}$. Hebrajczykami byliby natomiast judeochrześcijanie, pochodzących z Palestyny. Oni posługiwali się językiem aramejskim i czytali Biblię po hebrajsku. Mielibyśmy zatem do czynienia $\mathrm{z}$ napięciem między dwoma grupami judeochrześcijan, które wyraża się tym, że Hebrajczycy zaniedbują wdowy, wywodzące się z Hellenistów. Z informacji tej możemy wnioskować, że troska o wdowy i ubogich spoczywała zwłaszcza na judeochrześcijanach wywodzących się $\mathrm{z}$ judaizmu palestyńskiego ${ }^{48}$. Wydaje się także z kontekstu, że odpowiedzialni

46 Do 6,1 uczniami byli określani wyłącznie Apostołowie. Od tego miejsca termin ten oznacza wszystkich wyznawców Jezusa. Zob. J.A. Fitzmyer, Gli Atti degli Apostoli, s. 345-346.

47 Nie wszyscy komentatorzy podzielają ten pogląd. Inna możliwość rozumienia terminu „Helleniści” to Żydzi odłączeni od oficjalnego judaizmu, np. należący do wspólnoty w Qumran lub poganie, którzy przyjęli chrześcijaństwo (etnochrześcijanie), co mogłoby być potwierdzone przez fakt, że wybrani diakoni noszą imiona greckie (choć samo imię nie musi jeszcze wskazywać na pochodzenie z pogaństwa), a o Mikołaju mówi się wprost, że był prozelitą (poganinem) z Antiochii (6,5), zob. P. Ostański, Studzy Ewangelii w Dziejach, s. 258-260.265-266.; R. Pesch, Atti degli Apostoli, s. 299; J.A. Fitzmyer, Gli Atti degli Apostoli, s. $346-347$

48 Jeśli takie zaniedbywanie miało miejsce, może ono być świadectwem pewnych napięć między dwoma ugrupowaniami judeochrześcijan. Według G. Stählin, $\chi \eta ́ p \alpha, k$. 733-734 nie jest wykluczone, że wielu judeochrześcijan z diaspory osiedlało się w Jerozolimie, 
byli sami Apostołowie ${ }^{49}$. Łukasz nie precyzuje o jaki rodzaj zaniedbania cho-

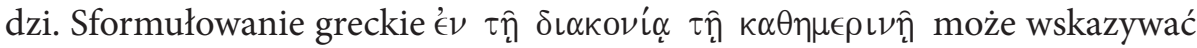
na udzielanie pomocy w obsłudze codziennej, a powtórzony dwukrotnie rodzajnik oznacza, że chodzi o jaką́s posługę znaną i praktykowaną, być może codzienny rozdział pomocy (w sensie 4,35: „Rozdzielano każdemu według po-

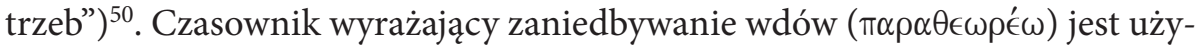
ty w imperfectum, co wskazuje na powtarzającą się sytuację. Wzmianka ta jest jednoznacznym świadectwem, że wspólnota pierwotnego Kościoła troszczyła się i to każdego dnia o potrzeby wdów, które ubogie i często pozbawione środków do życia oczekiwały charytatywnej pomocy od współwyznawców Chrystusa. Potwierdza to także summarium opisujące życie wspólnoty: „Wszyscy wierzący stanowili jedno i wszystko mieli wspólne. Sprzedawali swoje posiadłości i majątki i rozdzielali je wszystkim stosownie do potrzeb” ( $\mathrm{Dz} 2,44-45$, także 4,32.37). Kiedy pojawiło się zagrożenie, że ta posługa względem wdów może być osłabiona, natychmiast Apostołowie szukają rozwiązania, aby kontynuować dzieło pomocy. Jest to przecież jeden z motywów wyboru siedmiu diakonów, który zostają przeznaczeni głównie „do obsługiwania stołów” $(6,2-3)^{51}$. Decyzja grona apostolskiego („Dwunastu”) poparta przez zgromadzenie „wszystkich uczniów” (6,2) świadczy o wadze problemu i trosce o znalezienie jak najlepszego sposobu, który zagwarantuje stałą i na odpowiednim poziomie troskę o wdowy i innych ubogich, należących do wspólnoty uczniów Jezusa.

oddając swoje dobra do dyspozycji wspólnoty. Po ich śmierci pozostawały wdowy, które mogły liczyć wyłącznie na pomoc wspólnoty, gdyż nie miały krewnych in loco, którzy mogliby się nimi zaopiekować.

49 H. Langkammer, Dzieje Apostolskie, s. 86 zwraca uwagę, że nawet jeśli Apostołowie nie tylko byli bezpośrednio zaangażowani w dystrybucję dóbr i pomoc wdowom, to jednak odpowiedzialność za braki i niedociągnięcia w tej dziedzinie spadały na Apostołów.

50 E. Dąbrowski, Dzieje Apostolskie, s. 272; J.A. Fitzmyer, Gli Atti degli Apostoli, s. 348;

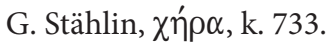

51 To wyrażenie też nie jest jasne do końca, na czym miała polegać posługa wybranych Siedmiu: czy chodzi o stoły, przy których spożywano posiłki, czy także o stoły, na których zbierano pieniądze (Łk 19,23). Zatem posługa polegała tylko na służbie podczas wspólnych agap i rozdzielaniu żywności, czy szerzej mogła oznaczać gromadzenie i rozdzielanie wszystkich dóbr materialnych, które były potrzebne wspólnocie. Ponadto przykład Szczepana i Filipa świadczy, że ustanowieni diakoni zajmowali się także głoszeniem Ewangelii. 


\section{Troska Tabity o wdowy $(9,36-43)$}

Kolejne dwa razy rzeczownik „wdowa” w liczbie mnogiej pojawia się w opowiadaniu o wskrzeszeniu Tabity. Apostoł Piotr podczas pobytu w Liddzie uzdrowił sparaliżowanego Eneasza, który od ośmiu lat nie wstawał ze swego łoża (Dz 9,32-34). W pobliskiej Joppie (= Jafa, około $20 \mathrm{~km}$ od Liddy) mieszkała chrześcijanka określona przez Łukasza jako „uczennica” ${ }^{52}$ o imieniu aramejskim Tabita, co po grecku znaczy Dorkas = Gazela $(9,36)$. Autor charakteryzuje tę kobietę w następujący sposób: „Była pełna dobrych uczynków i jałmużn,

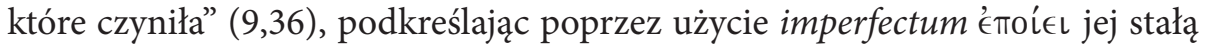
hojność i dobroduszność oraz opiekę nad biednymi, którą być może sprawowała także z upoważnienia wspólnoty ${ }^{53}$, stając się w ten sposób symbolem jej dobroci wobec potrzebujących ${ }^{54}$. Niestety zachorowała i umarła. Uczniowie przygotowali jej ciało do pogrzebu, obmywając je i składając w pokoju na piętrze $(9,27)$. A ponieważ Jafa była niedaleko Liddy posłali dwóch ludzi z próbą, aby Piotr możliwie jak najszybciej przybył do Jafy. Kiedy apostoł przybył do domu Tabity napotkał wdowy, które płaczem wyrażały swój żal z powodu śmierci ich miłosiernej dobrodziejki oraz jako dowód jej wspaniałomyślności pokazywały odzienia („tuniki i płaszcze”), które Dorkas dla nich zrobiła $(9,39)$.

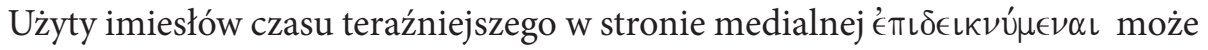
oznaczać, że wdowy miały na sobie ubiory, które otrzymały od zmarłej ${ }^{55}$. Jeśli uznać, że „tunika” (chiton) była szatą noszoną głównie przez kobiety wywodzące się z kultury greckiej, to można założyć, że chodzi o wdowy wychodzące się z Hellenistów, podobnie jak w 6,1.

Zwróćmy uwagę, że tak samo jak w opisie wskrzeszenia młodzieńca z Nain $(Ł k 7,11-17)^{56}$ nie ma wyraźnie sformułowanej prośby o cud. Piotr jednak kazał wszystkim opuścić pomieszczenie, a następnie po żarliwej modlitwie, dokonał

52 Zdaniem H. Langkammer, Dzieje Apostolskie, s. 138 świadczy to o żydowskim pochodzeniu Tabity, która mogła wywodzić się z synagogi helleńskiej, bo wspomniane tuniki (chitony) były spodnią szatą noszoną w krajach o kulturze helleńskiej głównie przez kobiety.

53 Zob. G. Stählin, $\chi \eta ́ \rho \alpha$, k. 734.

54 Zob. R. Pesch, Atti degli Apostoli, s. 435.

55 J.A. Fitzmyer, Gli Atti degli Apostoli, s. 457.

56 Na temat zależności opowiadania o uzdrowieniu w Jafie od tradycji starotestamentowych o Eliaszu i Elizeuszu (1 Krl 17,17-24 oraz 2 Krl 4,19-37), zob. R. Pesch, Atti degli Apostoli, s. 433. Zdaniem Pescha jest też możliwa zależność literacka i teologiczna od Mk 5,41 , gdzie występuje polecenie Jezusa „Talitha”, a tutaj odpowiednikiem byłoby imię uzdrowionej kobiety „Tabita” (s. 438). W ten sposób byłaby jeszcze bardziej wyeksponowane podobieństwo w działaniu Jezusa i apostoła Piotra. 
cudu wskrzeszenia Tabity $(9,40-41)^{57}$. Następnie przywołał „świętych ${ }^{58}$ i wdowy" i pokazał im ją żywą $(9,41)$. Według G. Stählina fakt, że wdowy są wymienione obok innych uczniów („świętych”) może świadczyć, że stanowią one już jakąś specjalną grupę we wspólnocie w Jafie ${ }^{59}$, o czym czytamy w $1 \mathrm{Tm}$ 5,3-5 ${ }^{60}$. Być może kolejna wzmianka o wdowach, które odzyskują swoją filantropkę, ma także ukazać Piotra, który podobnie jak Jezus, wskrzeszający jedynego syna wdowy z Nain, troszczy się w ten sposób o biednych i potrzebujących ${ }^{61}$. Apostoł naśladuje zatem Jezusa, uzdrawia Jego mocą, a tym samym przypomina wspólnocie wyznawców o konieczności stałej troski o bliźnich w potrzebie ${ }^{62}$.

\section{Wdowa adresatem Bożego i ludzkiego miłosierdzia}

Ewangelista Łukasz, którego średniowieczny poeta i filozof włoski Dante Alighieri nazwał „piewcą łagodności Chrystusa” („scriba mansuetudinis Christi" ${ }^{63}$ ) opisuje wydarzenia, które w szczególny sposób wskazują na miłość Jezusa do człowieka, zwłaszcza grzesznego oraz potrzebującego Bożej i ludzkiej pomocy. Wystarczy przypomnieć, że tylko w trzeciej Ewangelii odnajdujemy opowiadanie o nawróconej grzesznicy (7,36-50), o dwóch marnotrawnych synach i miłosiernym Ojcu (15,11-32), o Zacheuszu, celniku odnalezionym przez Chrystusa (19,2-10). Niewątpliwie zainteresowanie Łukasza wdowami wpisuje się w ten zamiar ukazania w Ewangelii najpierw samego Jezusa jako Tego, który swoim życiem i czynami potwierdza troskę Boga, Opiekuna wdów i sierot (Ps 68,6), wysłuchującego ich płaczu (Syr 35,12) i przychodzącego im z pomocą. Według Ewangelisty Łukasza to właśnie wdowy, a zatem kobiety znajdujące się w szczególnie trudnej sytuacji materialnej i społecznej, stają się

57 Nie ulega wątpliwości, że opis cudu wskrzeszenia Tabity w swoich istotnych elementach jest wzorowany na opisie cudu wskrzeszenia córki Jaira (Łk 8,49-56 oraz teksty paralelne). W ten sposób także Łukasz wyraża myśl, że apostoł Piotr kontynuuje dzieło samego Jezusa.

58 Jest to określenie chrześcijan.

59 G. Stählin, $\chi \eta ́ \rho \alpha$, k. 735.

60 Zob. P. Ostański, Skądże nadejdzie mi pomoc?, s. 69-72. Istnienie wspólnot wdów jako pewnej „instytucji” potwierdzają także Ojcowie apostolscy. Według autora artykułu „starożytny urząd wdów, naszkicowany przez Pawła w 1 Tm 5,9-15” jest „obecny zapewne w tle tekstów Dz 1,6 i Dz 9,9" (s. 74).

61 Zob. H. Langkammer, Dzieje Apostolskie, s. 138.

62 Zob. R. Pesch, Atti degli Apostoli, s. 439.

63 De Monarchia, I 16 2. Jest to łacińskie dzieło Dantego, które powstało na początku XIV w. 
adresatami Bożego zainteresowania i Bożej troski, urzeczywistnionej w Jezusie. On nie tylko dostrzega trudną ich sytuację, ale podejmuje działanie, które jest świadectwem Jego miłosierdzia (wdowa z Nain). W swoim nauczaniu jednoznacznie przestrzega przed wykorzystywaniem wdów $(20,47)$ oraz zachęca do zainteresowania się ich losem oraz udzielenia im konkretnej pomocy, na którą ostatecznie godzi się nawet niesprawiedliwy sędzia $(18,4)$.

Przedstawione w Ewangelii wdowy stają się symbolem (paradygmatem) całkowitej ufności wobec Boga, zwłaszcza w trudnej sytuacji życiowej, jakim jest sam stan wdowieństwa (prorokini Anna) lub w innych okolicznościach, które jeszcze bardziej potęgują trudności i stanowią niejednokrotnie zagrożenie życia, jak na przekład susza, a mimo to ufna i nawet gościnna postawa wdowy z Sarepty Sydońskiej $(4,26)$. Taka wytrwała i pełna zaufania postawa zostaje wynagrodzona nie tylko troską Boga o to, co niezbędne do życia, ale także łaską rozpoznania w Eliaszu proroka Jahwe, a w przypadku prorokini Anny możliwością zobaczenia i świadczenia o Mesjaszu wobec wszystkich, „którzy oczekiwali wyzwolenia Jeruzalem" $(2,38)$. Jak pisze ks. Ostański przywołując postać Judyty i prorokini Anny: „Ani w Judycie, ani w Annie nie widzimy najmniejszego śladu zgorzknienia, malkontenctwa, poczucia nieprzydatności czy chociażby kobiecej słabości. Pomimo wdowieństwa i podeszłego wieku (obie miały po około sto pięć lat) żadna z nich nie czuła się samotna, Ich życie i pustkę po mężu wypełniała służba dla Boga i dla ludzi”64.

Łukaszowe wdowy są także przykładem całkowitego powierzenia się Bogu. Nie mogą liczyć na to, co posiadają, a nawet z tego, co mają, potrafią jeszcze złożyć Bogu ofiarę (21,1-4). W ten sposób ich życie ubogie, pełne trosk i przeciwności, ale przeżywane w oddaniu się Bogu, staje się miłą Jemu ofiarą $(4,37)$. Ponadto nieustępliwa wdowa jest także symbolem nieustającego wołania i zanoszenia do Boga ufnej prośby, aby Ten, obronił ją przed jej przeciwnikiem $(18,3)$. Taka wytrwała modlitwa nie pozostaje bez odpowiedzi, bo przecież Bóg wysłuchuje płaczu wdów (Wj 22,21-23) i traktuje je z czułością na równi z sierotami i przychodniami (Ps 146,9).

Miłosierna postawa Jezusa wobec wdów, tak bardzo akcentowana przez ewangelistę Łukasza, staje się przykładem do naśladowania przez Jego wyznawców. Daje temu wyraz Łukasz w Dziejach Apostolskich, kiedy pisze o trosce pierwotnego Kościoła o wdowy. Gdy pojawiło się niebezpieczeństwo zaniedbywania tej posługi charytatywnej wobec nich, Apostołowie od razu znaleźli skuteczne rozwiązanie, wybierając diakonów, którzy mieli za zadanie troskę o potrzebujących $(6,3)$. Świadczy to, że świadomość konieczności opieki nad

\footnotetext{
64 P. Ostański, Skądże nadejdzie mi pomoc?, s. 68.
} 
najsłabszymi we wspólnocie była bardzo żywa i kształtowała codzienną postawę uczniów Jezusa.

Wymownym przykładem, także godnym naśladowania, są dzieła chrześcijanki z Jafy, Tabity, która dawała hojne jałmużny, czyniła wiele dobrego, zwłaszcza wobec tamtejszych wdów, dostarczając im odpowiedniego odzienia. To właśnie jest śmierć najbardziej dotknęła te kobiety, które korzystały z jej dobroci i miłosierdzia. Cud wskrzeszenia Tabity dokonany przez Piotra może być także rozumiany jako kontynuacja misji samego Jezusa, będącej wyrazem także Jego szczególnej troski o potrzebujących, a zwłaszcza o wdowy.

W kontekście sympozjum o „Przemocy wobec kobiet w Biblii?” 65 trzeba jednoznacznie zaznaczyć, że w Opus Lucanum nie znajdujemy jakiejkolwiek nawet sugestii o przemocy wobec wdów. Co więcej, analizowane teksty zobowiązują wyznawców Jezusa do swoistego rodzaju miłosiernej łagodności wobec potrzebujących kobiet, jakimi są niewątpliwie wdowy. Jednoznacznie przestrzegają przed jakąkolwiek formą ucisku i wykorzystywania ich słabej społecznie pozycji. Piętnują wszelkie tego typu zachowania, jak objadanie domów wdów przez faryzeuszy $(20,47)$ oraz brak zainteresowania ich trudnym losem i odmowa pomocy, jak w przypadku niesprawiedliwego sędziego $(18,4)$, czy jakąkolwiek formę zaniedbywania posługi charytatywnej (Dz 6,1). Zwłaszcza Dzieje Apostolskie, które ukazują pierwsze lata życia wspólnoty uczniów Jezusa, zalecają jednoznacznie nawet swoistego rodzaju „strukturalną” opieką nad wdowami, myśl, która zostanie rozwinięta przez tradycję Pawłową, zwłaszcza w listach pasterskich ${ }^{66}$. W świetle powyższych rozważań szczególnie wymowne są słowa, które czytamy w Liście św. Jakuba: „Człowiekiem religijnym i nieskazitelnie czystym przed Bogiem Ojcem jest ten, kto sierotom i wdowom przychodzi $\mathrm{z}$ pomocą w ich utrapieniu, a siebie samego zachowuje czystym od skazy świata" $(1,27)$. Postulat ten pozostaje ciągle aktualny i zobowiązujący, a realizowany w życiu pojedynczego ucznia Jezusa i całej wspólnoty chrześcijańskiej jest wymownym świadectwem wierności Jezusowi i Jego Ewangelii.

\section{Bibliografia}

Banaszek A., Prawdziwa pobożność ubogiej wdowy (Mk 12,41-44; Łk 21,1-4), w: W. Chrostowski (red.), Przybliżyło się Królestwo Boże, Warszawa 2008, s. 61-73. Bednarczyk M., Perykopa o Annie prorokini (Łk 2,36-38) w świetle wspótczesnych badań, „Novum” 4 (1980), s. 64-83.

Zob. przypis 6.

66

Zob. P. Ostański, Skądże nadejdzie mi pomoc?, s. 68-73. 
Bednarz M., Bierz i czytaj, cz. 1, Tarnów ${ }^{2} 2000$.

Dąbrowski E., Dzieje Apostolskie, Poznań 1961.

Fausti S., Wspólnota czyta Ewangelię według św. Łukasza, Częstochowa 2006.

Fitzmyer J.A., Gli Atti degli Apostoli, Brescia 2003.

Jan Paweł II, Dives in misericordia, http://www.opoka.org.pl/biblioteka/W/WP/jan_ pawel_ii/encykliki/dives.html\#m1 [dostęp 28.04.2015].

Kotecki D., „Droga” jako element jedności literacko-teologicznej Ewangelii Łukasza i Dziejów Apostolskich, „Biblica et Patristica Thoruniensia” 1 (2008), s. 55-76. DOI: http://dx.doi.org/10.12775/BPTh.2008.003.

Langkammer H., Dzieje Apostolskie, Lublin 2008.

Langkammer H., Znaczenie o rola kobiety w pierwotnym Kościele, „Zeszyty Naukowe KUL” 38 (1995) 1-2, s. 45-53.

Mickiewicz Fr., Ewangelia według świętego Łukasza. Rozdziały 1-11, cz. 1, Częstochowa 2011.

Mickiewicz Fr., Ewangelia według świętego Łukasza. Rozdziały 12-24, cz. 2, Częstochowa 2012.

Mikołajczak M., Proklamacja tożsamości Jezusa wświątyni jerozolimskiej (Łk 2,25-38), „Premislia Christiana” 8 (1999), s. 183-195.

Mourlon Beernaert P., Maria, Marta i inne. Wizerunki kobiet w Ewangelii, Kraków 1997.

Ostański P., Skądże nadejdzie mi pomoc? (Ps 121,1). Wokół wdowieństwa w Biblii, „Poznańskie Studia Teologiczne” 16 (2004), s. 59-74.

Ostański P., Studzy Ewangelii w Dziejach, w: J.K. Pytel (red.), Księga Dziejów Apostolskich, Szczecin 1999, s. 227-281.

Paciorek A., Przypowieści Jezusa. Wprowadzenie i objaśnienie, Częstochowa 2013.

Pesch R., Atti degli Apostoli, Assisi 1992.

Pismo Święte Starego i Nowego Testamentu. Nowy Testament, t. 4, Poznań 1994.

Rakocy W., „Będziecie moimi świadkami...”(Dz 1,8) (Dzieje Apostolskie), w: J. Frankowski, S. Mędala (red.), Dzieje Apostolskie, Listy św. Pawła, Warszawa 1997, s. 13-81.

Remaud, M. Prophétesse et fille d'Asher, „Cahiers Ratisbonne” 1 (1996), s. 31-46.

Rubinkiewicz R., Pozycja społeczna kobiety w świetle Ewangelii, „Zeszyty Naukowe KUL” 38 (1995) 1-2, s. 55-65.

Schürmann H., Il vangelo di Luca, cz. 1, Brescia 1983.

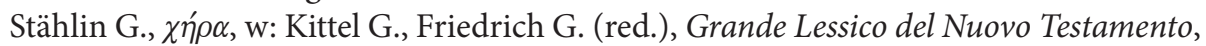
t. XV, Brescia 1998, k. 703-772.

Szymik S., Małżeństwo i rodzina w Biblii, w: G. Witaszek (red.), Życie społeczne w Biblii, Lublin 1998, s. 203-225.

Vermes G., Twarze Jezusa, Kraków 2008.

Wdowa, w: Ryken L., Wilhoit J.C., Longman III T., Słownik symboliki biblijnej, Warszawa 1998, s. 1074-1075.

Wojciechowski M., Wady jako zalety. Trzy trudne przypowieści Jezusa (Łk 16,1-8a; 18,1-8a; 11,5-8), „Ateneum Kapłańskie” (2005) 578, s. 111-119. 